\title{
Validitas Game Edukasi Klasifikasi Tumbuhan Berbasis Permainan Koa sebagai Media Pembelajaran Biologi
}

\author{
Rahmadhani Fitri ${ }^{*}$, Relsas Yogica ${ }^{2}$ \\ ${ }^{1,2)}$ Jurusan Biologi, FMIPA, Universitas Negeri Padang, Padang, Indonesia
}

Pengiriman: 13 September 2018; Diterima: 2 Oktober 2018; Publikasi: Nopember 2018

\begin{abstract}
The results of observations, not many teachers or lecturers who use educational games are mainly to facilitate students in learning material about taxonomy, especially the classification of plants. Educational game classification of plants based on the koa game is expected to function to facilitate students in learning the classifications that are classified as difficult to memorize. This research is research development. Data collection was carried out by expert validation of educational games and data were analyzed using descriptive statistical analysis. Based on the results of the game education analysis obtained the value of the validity of the game education classification of plants is 89.13 with valid criteria. It can be concluded that the educational game based on koa game is valid, and practicality tests can be done to see the level of practicality of the game.
\end{abstract}

Keywords: Validity, Educational Game, Koa Game

\begin{abstract}
ABSTRAK: Berdasarkan hasil observasi yang dilakukan, belum banyak guru ataupun dosen yang menggunakan game edukasi terutama untuk memudahkan peserta didik dalam mempelajari materi mengenai taksonomi khususnya klasifikasi tumbuhan. Game edukasi klasifikasi tumbuhan berbasis permainan koa diharapkan dapat berfungsi untuk memudahkan peserta didik dalam mempelajari klasifikasi yang tergolong susah untuk dihafalkan. Penelitian ini merupakan penelitian pengembangan. Pengumpulan data dilakukan dengan memvalidasi game edukasi oleh pakar dan data dianalisis menggunakan analisis statistik deskriptif. Berdasarkan hasil analisis game edukasi didapatkan nilai validitas game edukasi klasifikasi tumbuhan adalah 89,13 dengan kriteria valid. Dapat disimpulkan bahwa telah dihasilkan game edukasi berbasis permainan koa yang valid dan selanjutnya dapat dilakukan uji praktikalitas untuk melihat tingkat kepraktisan game tersebut.
\end{abstract}

Kata Kunci: Validitas, Game Edukasi, Permainan Koa

*Penulis Korespondensi:

Alamat surel: rahmadhanifitri@fmipa.unp.ac.id 


\section{PENDAHULUAN}

Pada saat ini, peserta didik lebih senang bermain game daripada belajar atau membaca buku. Oleh karena itu, diperlukan variasi dalam proses pembelajaran dengan menggunakan media pembelajaran berbentuk game edukasi. Game edukasi memudahkan peserta didik dalam memahami pelajaran yang akan diajarkan dengan metode yang menyenangkan sehingga peserta didik tidak bosan dengan metode pembelajaran yang biasa digunakan oleh guru berupa ceramah, diskusi, atau tanya jawab.

Game edukasi ini tidak hanya digunakan untuk peserta didik di sekolah dasar atau menengah saja. Akan tetapi game edukasi ini dapat digunakan untuk peserta didik yang ada diperguruan tinggi. Seperti yang disampaikan Handriyantini (2009) bahwa game edukasi adalah permaianan yang dirancang atau dibuat untuk merangsang daya pikir termasuk meningkatkan konsentrasi dan memecahkan masalah. Artinya,game edukasi ini dapat diperuntukkan bagipeserta didik yang ada di sekolah dasar, menengah,ataupun perguruan tinggi. Hal ini disebabkan oleh kecenderungan seseorang yang suka dengan permainan atau game.

Game Edukasi adalah salah satu jenis media pembelajaran yang digunakan untuk memberikan pengajaran, menambah penge-tahuan penggunanya melalui suatu media unik dan menarik. Game edukasi dibuat dengan tujuan spesifik sebagai alat pendidikan, untuk belajar mengenal warna, mengenal huruf dan angka, matematika, sampai belajar bahasa asing.

Game dengan tujuan edukasi seperti ini dapat digunakan sebagai salah satu media edukasi yang memiliki pola pembelajaran learning by doing.
Berdasarkan pola yang dimiliki oleh game tersebut, pemain dituntut untuk belajar sehingga dapat menyelesaikan permasalahan yang ada. Berdasarkan uraian tersebut maka dapat disimpulkan bahwa game edukasi adalah salah satu bentuk game yang dapat berguna untuk menunjang proses pembelajaran secara lebih menyenangkan dan lebih kreatif, dan digunakan untuk memberikan pengajaran atau menambah pengetahuan penggunanya melalui suatu media yang menarik.

Berdasarkan hasil penelitian sebelumnya, Anggraini, dkk., (2016) dan Sari, dkk., (2014) bahwa game edukasi dapat menunjang proses pembelajaran. Hasil penelitian Anggraini, dkk., (2016) menyatakan bahwa game edukasi dapat digunakan sebagai media pembelajaran yang menarik dan menyenangkan bagi siswa sehingga mereka lebih tertarik untuk mempelajari materi pelajarannya. Hasil penelitian Sari (2014) juga menyatakan bahwa game edukasi dapat membantu siswa untuk memahami materi pelajarannya.

Selain itu, menurut Vitianingsih (2016) game edukasi biasa digunakan sebagai media alternatif pembelajaran guru dalam mengubah cara belajar konvensional menjadi cara belajar simulasi game, sehingga dapat mengembangkan kreativitas siswa karena dalam game edukasi memiliki unsur tantangan, ketepatan, daya nalar, dan etika.

Koa atau Ceki adalah salah satu permainan yang umum dimainkan oleh laki-laki minang. Seringkali permainan ini dianggap sebagai judi. Tidak salah dan tidak sepenuhnya benar. Ada orang yang murni sekedar bermain saja, sedangkan taruhan kecil kecilan, seperti rokok dan teh talua, hanya untuk menambah seru permainan (Firdaus, 2016). 
Permainan kartu hitam putih ini diduga berasal dari kebudayaan China keturunan yang tinggal di wilayah sekitar selat malaka (singapura dan malaysia), kemudian menyebar luas dibawa oleh orang-orang melayu, bahkan hingga ke Minangkabau. Meskipun awalnya permainan ini dimainkan oleh kaum perempuan, sekarang bahkan permainan ini dianggap permainan kaum laki-laki. Di minangkabau sendiri, koa bahkan sudah dianggap menjadi permainan anak nagari.

Sumbarancak (2015) juga menyampaikan bahwa bagi pemula yang ingin belajar bermain koa diwajibkan untuk menghafal nama dari masingmasing kartu tersebut, karena pemenang dari permainan koa adalah player yang bisa menyamai kartu-kartu sesuai jenis nya. Cara bermain kartu koa sebenarnya menerapkan prinsip klasifikasi dalam menentukan siapa pemenang dari permainan yang dilakukan.

Karena itu, materi klasifikasi atau pengelompokan makhluk hidup khususnya klasifikasi tumbuhan cocok dibuatkan game edukasi berbasis permainan koa ini, Hal ini diharapkan akan sangat membantu dalam pembelajaran jika materi klasifikasi diajarkan menggunakan prinsip klasifikasi yang ada pada permainan koa. Materi klasifikasi tumbuhan ini tidak hanya dipelajari di perguruan tinggi saja (khususnya untuk mahasiswa jurusan biologi) akan tetapi juga dipelajari oleh siswa sekolah menengah terutama siswa sekolah menengah atas pada materi kingdom plantae.

Dari observasi yang dilakukan, belum banyak guru atau dosen yang menggunakan game edukasi ini terutama untuk memudahkan dalam mempelajari materi mengenai taksonomi khususnya klasifikasi tumbuhan. Karena itu penulis tertarik untuk melakukan penelitian yang bertujuan untuk mengembangkan game edukasi klasifikasi tumbuhan berbasis permainan koa sebagai media pembelajaran yang valid untuk peserta didik baik itu di Sekolah Menengah Atas (SMA) maupun di perguruan tinggi.

\section{METODE PENELITIAN}

Penelitian ini merupakan penelitian pengembangan (Research and the Development) untuk menghasilkan produk baru, yaitu Game Edukasi Klasifikasi Tumbuhan Berbasis Permainan Koa sebagai Media Pembelajaran Biologi. Model pengembangannya adalah model pengembangan 4D (four D Models) yang terdiri dari empat tahap. Menurut Thiagajaran, Semmel, dan Semmel dalam Trianto (2012: 93) tahapan-tahapan dari model pengembangan 4-D adalah: pendefinisian (define), perancangan (design), pengembangan (develop) dan penyebaran (disseminate). Pada penelitian ini, peneliti hanya melakukannya tahapannya sampai tahap develop khususnya sampai tahapan validasi produk oleh pakar. Instrumen yang digunakan berupa lembar validasi. Data hasil validasi produk dianalisis menggunakan teknik analisis statistik deskriptif. Data hasil validasi game edukasi yang diperoleh, dianalisis terhadap seluruh aspek yang disajikan dalam bentuk tabel menggunakan skala Likert, selanjutnya dicari rata-rata nilai dengan menggunakan rumus yang dimodifikasi dari Hobri dalam Prasetiyo dan Sumarno (Tanpa tahun) berikut ini. 


$$
\mathrm{Va}=\frac{\sum_{\mathrm{i}=1}^{\mathrm{n}} \mathrm{Ai}}{\mathrm{n}} \times 100 \%
$$

Keterangan:

$\mathrm{Va}=$ rata-rata hasil penilaian validitas para ahli

$\mathrm{Ai} \quad=$ rata-rata penilaian validitas para ahli terhadap kriteria $\mathrm{i}$

n = banyaknya kriteria

Kriteria tingkat kevalidan (Va) adalah:

$$
\begin{array}{ll}
91 \%-100 \% & =\text { sangat valid } \\
81 \%-90 \% & =\text { valid } \\
71 \%-80 \% & =\text { cukup valid } \\
51 \%-70 \% & =\text { tidak valid } \\
51 \%< & =\text { sangat valid }
\end{array}
$$

(Dimodifikasi dari Purwanto, 2009).

\section{HASIL DAN PEMBAHASAN}

\section{A. Tahap Pendefinisian}

Pada tahapan ini dilakukan analisis siswa, analisis konsep, dan menyusun tujuan pembelajaran pada materi klasifikasi tumbuhan. Berdasarkan hasil wawancara peneliti dengan salah seorang guru biologi kelas X SMA diketahui bahwa materi tentang kingdom plantae terutama klasifikasi tumbuhan yang diajarkan kepada peserta didik hanya sampai tingkatan Classis beserta contoh spesies tumbuhannya yang diketahui oleh peserta didik. Untuk materi sampai tingkatan Ordo tidak disampaikan oleh guru di kelas. Materi tumbuhan sampai tingkatan Ordo ini pada umumnya disampaikan hanya untuk peserta didik yang mengikuti Olimpiade Biologi. Guru hanya meminta peserta didik mencari dan belajar mandiri jika ingin mengetahui materi ini lebih dalam dan lanjut lagi. Materi tentang klasifikasi tumbuhan ini diajarkan sesuai dengan tuntutan Kompetesi Dasar dan Lulusan peserta didik SMA. Kompetensi Dasar materi klasifikasi tumbuhan untuk peserta didik SMA Kurikulum 2013 sebagai berikut.

\section{Kompetensi Dasar}

3.3 Menerapkan prinsip klasifikasi untuk menggolongkan tumbuhan ke dalam divisio berdasarkan pengamatan morfologi dan metagenesis tumbuhan serta mengaitkan perannnya dalam keberlangsungan kehidupan di bumi

3.4 Menyajikan data tentang morfologi dan peran tumbuhan pada berbagai aspek kehidupan dalam bentuk laporan tertulis.

Materi klasifikasi tumbuhan ini tidak hanya diajarkan dan diperuntukkan bagi peserta didik SMA saja tetapi juga mahasiswa yang kuliah di Jurusan Biologi khususnya Jurusan Biologi Universitas Negeri Padang. Wawancara peneliti dengan salah seorang dosen biologi yang mengampu mata kuliah taksonomi tumbuhan diketahui bahwa batasan materi yang diajarkan pada mahasiswa adalah sampai pada tingkatan Familia beserta contoh-contoh spesies tumbuhan yang mewakili. Untuk Kurikulum KKNI Tahun 2013 materi mengenai klasifikasi tumbuhan ini diajarkan pada beberapa mata kuliah yaitu taksonomi tumbuhan tingkat rendah dan taksonomi tumbuhan tingkat tinggi untuk mahasiswa Program Studi Pendidikan Biologi serta taksonomi tumbuhan untuk mahasiswa Program Studi Biologi. Pada Kurikulum KKNI Tahun 2017 untuk mahasiswa Program Studi Pendidikan Biologi materi klasifikasi tumbuhan ini diajarkan pada 
mata kuliah Keanekaragaman Tumbuhan sedangkan untuk mahasiswa Program Studi Biologi masih tetap sama dengan kurikulum sebelumnya.

Capaian pembelajaran yang harus dikuasai oleh mahasiswa calon guru atau saintis disusun oleh dosen pengampu dengan beberapa pertimbangan. Dosen pengampu memilih beberapa ordo tumbuhan yang dikenali mahasiswa dan banyak ditemukan di sekitar atau di lingkungan mahasiswa tinggal terutama ordo dan familia tumbuhan yang ada di daerah tropis (Indonesia). Selain itu berdasarkan hasil wawancara dengan salah seorang dosen pengampu mata kuliah taksonomi tumbuhan pemilihan materi atau ordo dan familia tumbuhan ini juga memperhatikan manfaat contoh-contoh spesies ordo atau familia tumbuhan dalam kehidupan sehari-hari. Divisio, classis dan ordo tumbuhan pada materi taksonomi tumbuhan yang harus dikuasi oleh mahasiswa sebagai berikut.

1. Divisio Bryophyta

2. Divisio Psilophyta

3. Divisio Lycophyta

4. Divisio Arthrophyta

5. Divisio Filicophyta

6. Divisio Spermatophyta

a. Sub-divisio Gymnospermae

1) Classis Cycadinae

2) Classis Ginkgoinae

3) Classis Coniferinae

4) Classis Gnetinae

b. Sub-divisio Angiospermae

1) Classis Monocotyledoneae a) Ordo Pandanales b) Ordo Spatiflorae/ Arales

c) Ordo Glumiflorae

d) Ordo Principes/ Arecales

e) Ordo Liliflorae/ Liliales

f) Ordo Farinosae

g) Ordo Scitamineae/ Zingiberales

h) Ordo Microspermae/ Orchidales

2) Classis Dicotyledoneae

a) Ordo Verticilatae

b) Ordo Piperales

c) Ordo Urticales

d) Ordo Santanales

e) Ordo Aristolochiales

f) Ordo Centrospermae

g) Ordo Ranales/ Polycarpiceae

h) Ordo Rosales

i) Ordo Malvales

j) Ordo Parietales

k) Ordo Myrtiflorae/ Myrtales

1) Ordo Tubiflorae/ Solanales

m) Ordo Rubiales

n) Ordo Cucurbitales

o) Ordo Campanulatae/ Asterales

Berdasarkan tahapan pendefinisian yang dilakukan dapat disimpulkan bahwa materi klasifikasi tumbuhan yang akan dibuat sebagai Game Edukasi dibatasi hanya pada materi SubDivisio Angiospermae. Hal ini dikarenakan kemudahan mencari contoh dan gambar-gambar dari contoh-contoh tumbuhan yang mewakili setiap Ordo tumbuhan yang dipelajari baik di SMA maupun di Perguruan Tinggi serta kebermanfaatan media pembelajaran bagi peserta didik sebagai perantara penyampaian materi oleh guru dan dosen. 


\section{B. Tahap Perancangan}

Pada tahapan ini dilakukan perancangan dari game edukasi klasifikasi tumbuhan. Game edukasi ini terdiri dari beberapa bagian yaitu kompetensi dasar materi klasifikasi tumbuhan, panduan permainan, kartu permainan, dan kunci jawaban. Pada bagian Kompetensi Dasar dan Capaian Pembelajaran disajikan materi yang harus dikuasi oleh siswa SMA dan mahasiswa yang mengikuti perkuliahan taksonomi tumbuhan atau keanekaragaman tumbuhan. Kompetensi Dasar dan Capaian Pembelajaran yang harus dimiliki oleh peserta didik sudah diuraikan pada bahagian tahap pendefinisian.

Panduan permainan disusun sedemikian rupa sehingga diharapkan peserta didik nantinya paham bagaimana melakukan permainan game edukasi klasifikasi tumbuhan berbasis permainan koa ini. Cuplikan hasil rancangan dari panduan permainan ini dapat dilihat pada Gambar 1 berikut ini.

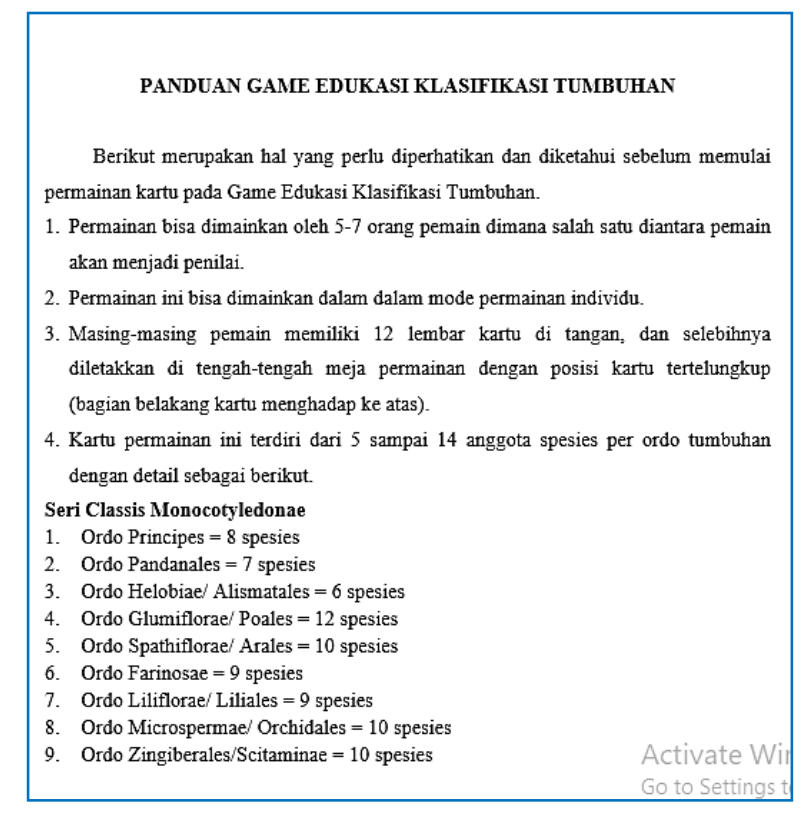

Gambar 1. Cuplikan Panduan Game Edukasi Klasifikasi Tumbuhan.
Game edukasi klasifikasi tumbuhan ini juga dilengkapi dengan kartu permainannya yang menjadi inti dari game tersebut. Bagian kartu ini terdiri dari dua sisi yaitu sisi depan dan sisi belakang. Pada bagian kartu dibuat dengan ukuran lebih kurang seperti kartu remi (kartu bridge) yaitu dengan lebar $6,19 \mathrm{~cm}(2,4$ inci) dan panjang 8,71 $\mathrm{cm}$ (3,4 inci) dengan pertimbangan bahwa jika dibuat seperti kartu permainan koa (ukuran 2,3 inci x 1,1 inci) maka ukuran kartu akan lebih kecil.

Pada bagian depan kartu akan diletakkan gambar dan nama spesies tumbuhan terpilih yang mewakili beberaoa ordo tumbuhan sesuai dengan Kompetensi Dasar dan Capaian Pembelajaran materi Klasifikasi Tumbuhan. Bagian sisi belakang ada identitas dari game edukasi dan gambar tumbuhan yang mewaliki contoh spesies dari SubDivisio Angiospermae. Karena adanya gambar dan nama yang dimasukkan kebagian sisi depan kartu maka ukuran kartu diperbesar lebih kurang sama dengan ukuran kartu remi agar gambar tumbuhan yang ada dan ukuran huruf nama spesies tumbuhan dapat dibaca menjadi lebih jelas. Karena pertimbangan ukuran kartu koa yang kecil ini dikhawatirkan jika gambar yang ada dan ukuran huruf pada kartu permainan tidak akan jelas oleh si pemain game edukasi klasifikasi tumbuhan nantinya.. Contoh desain kartu permainan ini dapat dilihat pada Gambar 2 berikut. 


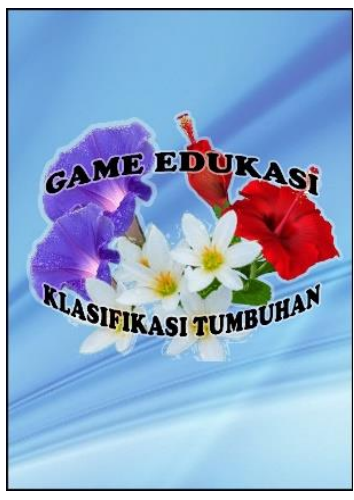

(a)

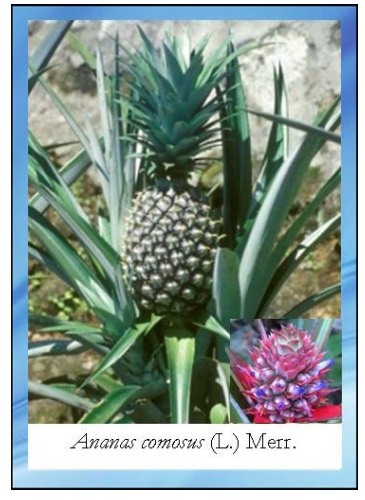

(b)
Gambar 2. Contoh Desain Kartu Permainan Game Edukasi Klasifikasi Tumbuhan. (a) Desain Kartu bagian Belakang, (b) Desain Kartu Bagian Depan.

\section{Tahap Pengembangan}

Pada tahap pengembangan dilakukan dua tahapan yaitu validasi produk dan uji praktikalitas produk. Proses validasi dilakukan oleh dua orang hai yaitu dosen biologi UNP (Ibu Dra. Des M., M.S sebagai validator ahli materi klasifikasi tumbuhan dan Ibu Ganda Hijrah Selaras sebagai validator ahli media pembelajaran). Tahapan validasi media dilakukan dengan memperhatikan beberapa aspek yaitu kelayakan isi, kebahasaan, penyajian, dan kegrafikaan. Hasil validasi produk penelitian berupa game edukasi disajikan pada Tabel 2 berikut.

Tabel 2. Hasil Analsis Validitas Game Edukasi Klasifikasi Tumbuhan

\begin{tabular}{clcc}
\hline No. & $\begin{array}{c}\text { Aspek } \\
\text { Penilaian }\end{array}$ & $\begin{array}{c}\text { Rerata Nilai } \\
\text { Validator }(\%)\end{array}$ & Kriteria \\
\hline 1 & Kelayakan Isi & 91,67 & Sangat Valid \\
2 & Kebahasaan & 86,67 & Valid \\
3 & Penyajian & 91,67 & Sangat Valid \\
4 & Kegrafikaan & 86 & Valid \\
\hline \multicolumn{2}{c}{ Rerata Validitas } & $\mathbf{8 9 , 1 3}$ & Valid \\
Kartu Permainan & &
\end{tabular}

Berdasarkan hasil analisis validitas game edukasi klasifikasi tumbuhan diketahui rerata nilai validasi yang diberikan oleh validator adalah 89,13\% dengan kriteria valid. Game edukasi klasifikasi tumbuhan berbasis permainan koa ini dinilai validator dapat dikadikan media pembelajaran bagi siswa ataupun mahasiswa yang mempelajari mengenai materi klasifikasi tumbuhan. Seperti yang disampaikan Pratiwi dkk. (2014) menyatakan bahwa modul pembelajaran biologi yang valid dapat digunakan sebagai media pembelajaran bagi siswa. Media pembelajaran yang dikembangkan ini dapat digunakan untuk membantu peserta didik mencapai tujuan pembelajaran. Media pembelajaran dinyatakan valid karena media dianggap dapat membantu peserta didik mengefisienkan belajarnya dan tidak hanya menghafal materi saja.

Game edukasi klasifikasi tumbuhan berbasis permainan koa yang valid ini dikarenakan materi yang ada pada game edukasi sesuai dengan Kompetensi dan Capaian Pembelajaran yang telah disusun oleh guru dan dosen. Seperti yang disampaikan Suswina (2011) bahwa media pembelajaran valid jika media yang tersebut dikembangkan telah sesuai dengan materi yang seharusnya. Hal ini juga didukung oleh pendapat Jaya dkk. (2014) bahwa media pembelajaran yang merupakan salah satu bagian dari perangkat pembelajaran yang dikembangkan dinyatakan valid karena media pembelajaran sudah sesuai dengan deskriptor yang ada pada instrumen penilaian. Selain itu Purwanto dan Yuliani (2013) juga menyatakan bahwa media pembelajran yang valid berarti media tersebut sudah sesuai dengan tujuan penelitian atau pengembang media sehingga 
validator memberikan penilaian yang layak untuk media tersebut digunakan sebagai perantara bagi pendidik kepada peserta didik menyampiakan materi pembelajaran.

\section{KESIMPULAN DAN SARAN}

Berdasarkan hasil penelitian yang telah dilakukan dapat disimpulkan bahwa telah dihasilkan game edukasi klasifikasi tumbuhan berbasis permainan koa sebagai media pembelajaran biologi yang valid dan selanjutnya dapat dilakukan uji praktikalitas untuk melihat tingkat kepraktisan game tersebut.

Saran untuk guru dan dosen, bahwa produk berupa game edukasi klasifikasi tumbuhan berbasis permainan koa dapat dijadikan sebagai salah satu alternatif media pembelajaran biologi yang dapat berfungsi untuk menyampaikan materi mengenai klasifikasi tumbuhan. Selain itu game edukasi ini juga diharapkan dapat berfungsi untuk mengubah cara belajar konvensional menjadi cara belajar dengan simulasi game, sehingga dapat mengembangkan kreativitas peserta didik karena dalam game edukasi memiliki unsur tantangan, ketepatan, daya nalar, dan etika. Hal ini dikarenakan media pembelajaran berupa game edukasi klasifikasi tumbuhan merupakan salah satu media yang berbasis permainan yang pada umumnya disukai dan dilakukan oleh siswa ataupun mahasiswa dalam kehidupan sehari-hari mereka.

\section{DAFTAR PUSTAKA}

Anggraini, A. F., N. Erviana, S. Anggraini, D. D. Prasetya. (2016). "Aplikasi Game Edukasi Petualngan Nusantara". Prosiding SENTIA,
Poleteknik Negeri Malang, Volume 8: 168172.

Firdaus, H. (2016). "Istilah, Cara dan Strategi dalam Main 'Koa' (Ceki) Untuk Pemula". www.wonderfulminangkabau.com/koaceki/, diakses 26 Januari 2018.

Handriyantini. (2009). Permainan Edukatif (Educational Games) Berbasis Komputer untuk Siswa Sekolah Dasar. Malang: Sekolah Tinggi Informasi dan Komputer Indonesia.

Jaya, I. M., I. W. Sadia, dan I. B. P. Arnyana. (2014). "Pengembangan Perangkat Pembelajran Biologi Bermuatan Pendidikan Karakter dengan Setting Guides Inquiry untuk Meningkatkan Karakter dan Hasil Belajar Siswa SMP”. e-Journal Program Pascasarjana Universitas Pendidikan Ganesha Program Studi Pendidikan IPA, Vol. 14: 1-12.

Prasetiyo dan Sumarno. (Tanpa tahun). "Pengembangan Perangkat Pembelajaran Biologi Materi Pengelolaan Limbah Berorientasi Kewirausahaan". isjd.pdii. lipi.go.id/admin/jurnal/11116372_20865481, diakses 10 Januari 2018.

Pratiwi, H. E., H.. Suwono, dan N. Handayani. (2014). "Pengembangan Modul Pembelajaran Biologi Berbasis Hybrid Learning ntuk Menuingkatkan Kemampuan Berpikir Kritis dan Hasil Belajar Siswa Kelas XI". Jurnal Online Universitas Negeri Malang, Pendidikan Hayati, Vol. 1, No.1: 112.

Purwanto, D., dan Yuliani. (2013). "Pengembangan Media Komik IPA Terpadu Tema Pencemaran Air sebagai Media Pembelajaran untuk Siswa SMP Kelas VII". Jurnal Pendidikan Sains e-Pensa, Vol. 01, No. 01: 71-76.

Purwanto, M. N. (2009). Prinsip-prinsip dan Teknik Evaluasi Pengajaran. Bandung: Remaja Rosdakarya.

Sari K. W., S. Saputro, dan B. Hastuti. (2014). "Pengembangan Game Edukasi Kimia Berbasis Role Playing Game (RPG) pada Materi Struktur Atom sebagai Media Pembelajaran Mandiri untuk Siswa Kelas X SMA di Kabupaten Purworejo. Jurnal Pendidikan Kimia, Vol. 3, No. 2: 96-104.

Sumbarrancak. (2014). "Istilah, Cara dan Strategi Jitu dalam Main Koa/ Ceki/ Pei”. tourdesumbar.wordpress.com/2015/09/23/ca ra-main-koa/, diakses 26 Januari 2018. 
Suswina M. (2011). "Hasil Validitas Pengembangan Bahan Ajar Bergambar Disertai Peta Konsep untuk Pembelajaran Biologi SMA Semester 1 Kelas XI". Ta'dib, Vol. 14, No. 1: 44-51.

Trianto. (2012). Model Pembelajaran Terpadu: Konsep, Strategi, dan Implementasinya dalam Kurikulum Tingkat Satuan Pendidikan (KTSP). Jakarta: Bumi Aksara.

Vitianingsih, A. V. (2016). "Game Edukasi sebagai Media Pembelajaran Pendidikan Anak Usia Dini”. Jurnal INFORM, Vol. 1, No. 1: 1-8. 